THE ANALYST.

41

\title{
ON THE WORK DONE BY THE PARIS MUNICIPAL LABORATORY.
}

By W. Douglas Hogg, M.D., of Parts.

Read before the Society of Public Analysts on the 15th December, 1882.

Some very important steps have lately been taken in France towards the suppression of adulteration. Laboratories have been opened and inspectors appointed by several municipal authorities, who, according to the French laws, have power to punish offences committed against the statutes concerning the adulteration of food.

The municipal council of the town of Paris, on the 27th October, 1880, ordered the establishment of a laboratory at the Prefecture of Police, which was consequently opened to the public on the 1st March, 1881. The example has this year been followed by Lyons, Marseilles, Bordeaux, Rouen, Ronbaix, Nantes, Lille, Montpellier, Melun, \&c.

The officials employed consist of a director, inspectors, and chemists holding scientific titles, and subjected to an examination on entering or being appointed, several occupying the grade of Pharmacion. We shall see by the following the list of the officers and employés. 
The inspector's duty is to take samples from those houses trading in provisions, and in the markets of the town, and they are assimilated for these functions with the Commissaires de Police. Their mode of operation is very simple. They present themselves in pairs at the place pointed out to them by a dissatisfied purchaser of a sample lately bought there, which on analysis at the laboratory had been found to be adulterated. They ask the tradesman to allow them to examine the products exposed for sale, and make a preliminary examination, either with a microscope or with the reagents enclosed in two small boxes which they carry with them. In case the products appear adulterated, the inspectors take two samples, sealed, numbered, and certified, both by them and the tradesman: one of these samples is analysed at the laboratory and the other is put aside in case of dispute. They draw up a proces verbal of seizure.

The daily employment of the inspectors is sent each day to the chief of the laboratory in the form of a report. This report contains the smallest details upon the healthiness of the establishment visited, the seizures made, and the destruction of unsound products.

It will be seen that the public are most important auxiliaries to the laboratory, as they report also upon articles they believe adulterated.

From the 1st March, 1881, the date of the opening of the municipal laboratory to the public, the latter have been invited, by means of notification, to cause to be analysed the drinks, provisions, and all articles of food used by them and of interest to health. At that time there was only one office at the Prefecture of Police. The samples were, and are still received by a comptroller, who inserts in a book kept for the purpose the nature of the sample, the date it was bought, the number of the depôt, the name and address of the depositor, and, lastly, the name, profession, and address, of the seller; then the comptroller extracts from a register a receipt which he remits to the depositor, indicating the date when the result of the analysis may be known.

The analyses are divided into two categories-one called qualitative (gratis) and the other quantitative (which are paid for). The first gives simply a report on the product deposited, without stating its composition, and confined to, or explained in, the following words :-Good, passable, bad (not injurious), bad (injurious).

The quantitative analyses, the fees for which vary, according to the nature of the samples, from 5 to 30 franes, give the exact composition of the product. Besides the receipt in this case, the comptroller detaches a note to pay into the municipal treasury.

It was very soon found that one office was insufficient, and to avoid a loss of time to the public, M. le Prefet de Police authorized the Commissaires de Police of the district to accept samples for qualitative analyses only. The samples sent to the bureau of police are placed in a chest ad hoc, and brought each day to the laboratory by the prison van, together with the samples taken by the chemical inspectors during their visits to the tradesmen.

Every product which enters the laboratory, whatever may be its nature, is analysed quantitatively, and it is upon the figures obtained that the chief of the laboratory bases his opinion.

Each analysis is registered in a book for the purpose, which remains at the laboratory and forms part of an important collection.

Besides the samples received from the public and from the inspectors, the laboratory 
has to treat daily a great number of samples from the Prefecture of the Police, the octroi of Paris, the hospitals, the prisons, \&c., \&c.

WORE OF THE IJABORATORY.-The routine of the laboratory is confined to the analyses, chemical and physical, of the articles which are sent. It does not value, but simply gives an appreciation, which is transmitted to the Prefet de Police. The reports are, further, handed down to the public prosecutor, who institutes proceedings against the offenders.

The attention of the laboratory has, from the beginning, been called to the determination of the normal composition of articles of food. With this object, most careful analyses have been made of numerous samples of wine, vinegar, beer, cider, spirits, syrups, water, milk, butter, oil, flour, bread, \&c. The results obtained on wine and milk are noted further.

Photographic apparatus has been provided, affording the analysts the advantage of putting before the eyes of the jury and judges a palpable proof of the detected adulteration -for instance, in pepper, flour, and confections-or showing them the presence of trichini, cysticerci, \&c.

The following table illustrates the number and quality of samples examined monthly during the year 1881 :-

\begin{tabular}{|c|c|c|c|c|c|c|c|c|}
\hline \multirow{3}{*}{$\begin{array}{l}\text { Month. } \\
\text { March }\end{array}$} & \multirow{2}{*}{\multicolumn{3}{|c|}{ Namber of Samples. }} & \multicolumn{5}{|c|}{ Pergentace of Adulteration. } \\
\hline & & & & Milk. & & Wine. & & $\begin{array}{l}\text { Iated on sam- } \\
\text { of all classes- }\end{array}$ \\
\hline & ... & 504 & $\cdots$ & $51 \cdot 40$ & $\cdots$ & $62 \cdot 30$ & $\ldots$ & $54 \cdot 50$ \\
\hline April & ... & 583 & ... & $56 \cdot 40$ & ... & $74 \cdot 10$ & $\ldots$ & $49 \cdot 30$ \\
\hline May & ... & 672 & ... & $79 \cdot 00$ & ... & $79 \cdot 60$ & ... & $63 \cdot 40$ \\
\hline June & ... & 760 & $\ldots$ & $66 \cdot 60$ & ... & $69 \cdot 80$ & $\ldots$ & $61 \cdot 50$ \\
\hline July & ... & 721 & $\cdots$ & $68 \cdot 20$ & $\cdots$ & $50 \cdot 70$ & $\ldots$ & $55 \cdot 40$ \\
\hline Angust & ... & 619 & $\cdots$ & $59 \cdot 70$ & ... & $55 \cdot 80$ & ... & $52 \cdot 80$ \\
\hline September & $\ldots$ & 606 & $\ldots$ & $30 \cdot 90$ & $\ldots$ & $60 \cdot 20$ & $\ldots$ & $51 \cdot 40$ \\
\hline October & $\ldots$ & 691 & $\ldots$ & $31 \cdot 00$ & $\ldots$ & $42 \cdot 20$ & $\ldots$ & $38 \cdot 40$ \\
\hline November & ... & 634 & $\cdots$ & $17 \cdot 50$ & ... & $50 \cdot 80$ & $\ldots$ & $39 \cdot 70$ \\
\hline December & ... & 727 & $\cdots$ & $46 \cdot 00$ & $\ldots$ & $45 \cdot 20$ & ... & $37 \cdot 90$ \\
\hline & & 517 & & $50 \cdot 67$ & & $59 \cdot 17$ & & 50.48 \\
\hline
\end{tabular}

These 6517 samples can be also classified as follows :-

$\begin{array}{lllllll}\text { Good } & \ldots & \ldots & \ldots & \ldots & \ldots & 1565 \\ \text { Passable } & \ldots & \ldots & \ldots & \ldots & \ldots & 1523 \\ \text { Bad (not injurious) } & \ldots & \ldots & \ldots & 2608 \\ \text { Bad (injurious) } & \ldots & \ldots & \ldots & \ldots & 562 \\ \end{array}$

The 259 remaining samples were still under examination at the end of 1881 .

Examinations of Wine.-The average of 2000 samples of wine have been found to contain-

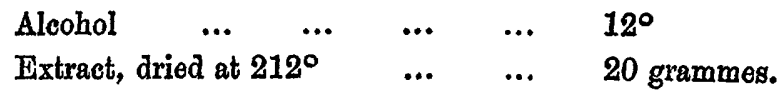

The allowed percentage for wines commercially sold has been lowered to-

$\begin{array}{llllll}\text { Alcohol } & \ldots & \ldots & \ldots & . & 10^{\circ} \\ \text { Dry extract } & \ldots & \ldots & \ldots & \ldots & 20 \text { grammes. }\end{array}$


Wine has been found to be commonly adulterated by addition of water to the extent of 20,30 , and even 50 per cent.

Examination of Milk. - The same process was followed concerning milk. After analysing 900 samples of divers origin, the normal composition was found to be-

$\begin{array}{lllll}\text { Density } \ldots & \ldots & \ldots & 1033 \\ \text { Cremometer } & \ldots & \ldots & 10^{\circ} \\ \text { Water } \ldots & \ldots & \ldots & 87 \text { grammes per cent. } \\ \text { Residue at } 95^{\circ} & \text { C... } & \ldots & 13 \quad, \quad \text { ". }\end{array}$

The residue is composed of-

$\begin{array}{llllll}\text { Ash } . . & \ldots & \ldots & \ldots & 0.60 \text { gr. } & \text { per cent. } \\ \text { Butter } & \ldots & \ldots & \ldots & 4.00, & , \\ \text { Lactine } & \ldots & \ldots & \ldots & 5.27, & , \\ \text { Casein and albumin... } & \ldots & 3.60, & ,\end{array}$

To be considered adulterated, milk must contain over 10 per cent. of water. This allowance may be regarded as very liberal, considering the great importance of milk as a food for infants. A small quantity of bicarbonate of soda is alsu tolerated, especially in the summer season.

The budget of the laboratory amounts to $\$ 5,200$, thus divided :-

$\begin{array}{lcccccr}1 \text { Director of the Laboratory... } & \ldots & \ldots & \ldots & 240 \\ 1 \text { Sub-director } & \ldots & \ldots & \ldots & \ldots & \ldots & 180 \\ 1 \text { Arralyst (1st class) ... } & \ldots & \ldots & \ldots & \ldots & 96 \\ \text { 3 ditto (2nd class) } & \ldots & \ldots & \ldots & \ldots & \ldots & 216 \\ 16 \text { Inspectors (1st class) } & \ldots & \ldots & \ldots & \ldots & 1,680 \\ 16 \text { ditto (2nd class) } & \ldots & \ldots & \ldots & \ldots & \ldots & 1,164 \\ \text { 3 Employés and Porters } & \ldots & \ldots & \ldots & \ldots & 200 \\ \text { General Expenses } & \ldots & \ldots & \ldots & \ldots & \ldots & 192 \\ \end{array}$

The rest of the sum is applied to the purchase of instruments, books, \&c.

The figures shown in the table should not be considered as strictly representing the state of things in France. It must be said that, up to very lately, the Paris laboratory was in reality the only one existing in the whole country. Consequently, the observations we had occasion to make at the last International Medical Congress, in order to explain the enormous percentage observed during the first five months, stand true for the whole year. We remarked that it would be unfair to say that over fifty articles of food out of a hundred are adulterated in France : for this reason, that the samples on which those percentages had been taken had, before being forwarded from all parts of the country to the laboratory, excited some suspicion as to their purity, and had been picked, so to say, from among many genuine articles. It is very difficult, upon these grounds, to form a correct opinion. The truth can only be got at by the examination of articles purchased indiscriminately wherever they are on sale. When this year's report is published, it will, in a certain measure, prove the correctness of our suggestions.

Last year's report has just been issued, forming a most valuable work, due to the pen of M. Charles Girard, Director of the Paris Laboratory, and a Member of this Society. 
I can only give a rapid sketch of this interesting compilation, taking among the numerous articles examined some of the most important adulterations.

It will be remarked that drugs are not comprised among the substances analysed. In France, pharmaciens are inspected by members of the School of Pharmacy, who alone have the right of entering in their officine.

Concerning milk, the report reads as follows :-

"The principal adulterations consist in the addition of water, and in the subtraction of cream : this fraud, though inoffensive for adults, must be considered as a most serious one when milk is employed for feeding young children. From the 1st of March, 1881, to the end of the year, 1,008 samples have been analysed-838 were brought in by the inspectors and 170 by the public. The percentage of adulteration in the first case was 45.46 per cent., and in the second case 46.79 per cent."

Divers substances have been detected in the milk-viz. : oatmeal, white of egg, dextrine, sugar, and even brain matter, oils, and fats. The majority of the samples adulterated were made up with extracts of milk and water, or ordinary milk deprived of its cream, to which water had been added in the proportion of 10 to 40 per cent.

The adulteration of wine is more complicated : mixed with water it loses its colour, and, consequently, some colouring substance must be added; likewise alcohols of inferior quality. M. Charles Girard values the loss annually sustained by the Treasury at more than $\$ 140,000$.

Wines manufactured with dried raisins, artificial ethers, cream of tartar, tannin, glycerine, \&c., have often come under the Parisian analysts' notice. Also wine containing oxide of lead, alum, salt, salicylic acid : sometimes arsenic in liquids coloured with fuchsine.

The number of samples examined were 3,361 , which can be classified as follows:-

Unhealthy wines (acid, bitter, musty) $\quad \ldots \quad \ldots \quad \ldots \quad \ldots \quad 6.51$ per 100.

$\begin{array}{lllllllll}\text { Mixture of different wines ... } & \ldots & \ldots & \ldots & \ldots & 9.55 & \text {, }\end{array}$

Containing less than one or two grammes of plaster $\quad \ldots \quad 24 \cdot 45 \quad$,

\begin{tabular}{|c|c|c|c|c|c|c|c|c|}
\hline \multirow{2}{*}{\multicolumn{2}{|c|}{$\begin{array}{c}\text { more } \\
\text { Mixed with water }\end{array}$}} & & \multirow{2}{*}{$\begin{array}{c} \\
\ldots \\
\ldots\end{array}$} & \multicolumn{2}{|c|}{ " } & \multicolumn{2}{|r|}{$75 \cdot 55$} & \multirow[t]{2}{*}{, } \\
\hline & & & & $\cdots$ & $\cdots$ & $\cdots$ & $41 \cdot 12$ & \\
\hline ugar and $d$ & caisins & ... & $\cdots$ & $\cdots$ & $\cdots$ & $\cdots$ & $3 \cdot 30$ & \\
\hline Artificially colc & & $\cdots$ & $\cdots$ & $\cdots$ & ... & $\cdots$ & $15 \cdot 65$ & \\
\hline alicylated .... & $\cdots$ & $\ldots$ & $\cdots$ & $\cdots$ & $\cdots$ & $\ldots$ & $4 \cdot 73$ & " \\
\hline alted & $\cdots$ & $\cdots$ & $\cdots$ & $\cdots$ & $\cdots$ & $\cdots$ & $0 \cdot 18$ & \\
\hline ntaining al & ... & $\ldots$ & $\cdots$ & $\ldots$ & ... & ... & $0 \cdot 029$ & \\
\hline
\end{tabular}

The substances most frequently employed in adulterating beer are : picric acid, gall, aloes, colocynth, cocculus indious, cubeb mixed already for use, with nux vomica and carbonate of soda, strychnine, box leaves, juniper, \&c.

Sixteen samples of spirits, out of 36 , were found adulterated-7 with foreign alcohols, 4 coloured artificially with burnt sugar, 5 with artificial essences. Of the 33 samples of liqueurs, 9 were coloured-5 containing fuchsine, 16 glucose. Sulphuric acid, copper, and dextrine were detected in vinegar; foreign fats and oils, and powdered date kernels, in chocolate; foreign vegetable substances, French chalk, residues of fecula manufactory, and powdered olive kernels, in pepper; colouring substances derived from lead, copper and arsenic, in syrups and jams ; \&c., \&c. 
Butter only gave 11 pure samples out of 62 examined, meal 13 out of 31 , bread 9 out of 13. Preserved vegetables were often found to contain copper-11 times out of 35 .

I regret not to be able to mention many other interesting points recorded by the eminent director; but I fear I have already trespassed on the space kindly granted me in these columns. Before ending, I will add that the endeavours of the laboratory have brought on a notable decrease in the number of adulterated articles sold in Paris and France generally. In a certain measure, the hopes expressed of late years, when the establishment of laboratories was being advocated, have been realized; and I am happy to have been able to contribute, in the limited measure of my means, to the founding of an institution which will produce, in time, most serviceable results.

NOTE ON REINSCH'S TEST.

By J, Madaluan, F.I.C., Chem. Demonstrator Royal Coli. Surgeons, Dublin. Read before the Society of Public Analysts on the 14th February, 1883.

IN testing for arsenic by Reinsch's method there is a serious source of error which seems to have been overlooked; at least, I can find no reference to it in any of the standard works on the subject. I allude to the deposition of free sulphur, together with cupric sulphide, on the copper, and its sublimation when heated. In examining decomposing organic substances sulphur is frequently deposited owing to the decomposition of free sulphuretted hydrogen, so much so, sometimes, as to take fire and burn with a blue flame when a lighted taper is applied to the copper. When heated in a tube, the sulphur forms a sublimate having a general appearance and behaviour similar to that of arsenious oxide, in small quantity being white and resubliming unaltered. It is mentioned in some works that sulphur cautiously sublimed condenses in rhombic octahedrons, but I have not found it deposit in that form. Under the microseope it is seen to consist of globules. When, however, these are so small as to render their outlines indistinct, they resemble closely the crystals of arsenious oxide in transparency, lustre, and aggregation. When doubt exists, the safest course might be to procure as much of the sublimate as possible, boil down a second time with dilute acid and copper, and examine any sublimate obtained, microscopically and with the usual confirmatory tests. 